\title{
InTERVIEW With Cynthia EnLoe
}

\author{
INTERVIEW CONDUCTED BY \\ Shelley Koch, Brian Tongier and Lisa-Marie Wright \\ Prepared By \\ Jose Martinez And Shelley Koch
}

STAR: What do you think is most important in doing good research?

Enloe: For the person doing it, you always hope you haven't peaked! I think of it in terms of what will be to you the most important work. In some ways I'm very glad that I started off doing ethnopolitics. Even though I look back on it now and realize that I had no gender consciousness at all. But there was no feminist analysis in the 50s and 60s. I'm glad that I started off as a Southeast Asia specialist working on Malaysia especially. And I'm really glad to have studied other countries and not the U.S. as a country. Malaysia was not a hot country to study; it was a country that most people didn't think was interesting. In fact, in Southeast Asia in the 1960s Indonesia was the hot place to do research because Indonesia was where nationalism was being formed and where revolution against the colonial power had taken place. Vietnam did not become analytically interesting to people until the late 60 s or early 70 s and actually there were still very few people who were specialists.

So when people at Berkeley thought Indonesia was the hot place, I was thinking that I wanted a country that was "boring." I wanted a country that other people imagined was not exciting or was not making waves; that is, was not the site for generating theory. And I always had this hunch that when people thought places were boring, they were making certain assumptions; if one dug 
deeper, however, it would prove interesting. And what that meant was that I got interested in ethno-politics. Because you can't study or try to understand Malaysia unless you're interested in ethnopolitics and ethno-politics there were-or still are- between ethnic Malays, who are the majority, ethnic Chinese, who have been there for generations, and ethnic Indians, most of whom are Tamils. And I came into Malaysia after the colonial rule but where I still saw planters and people in downtown Kuala Lumpur right out of a Somerset Maugham book.

But the colonial era was over. Chase Manhattan bank had just opened in Kuala Lumpur, the capital — mind you, this was the mid $60 \mathrm{~s}$. We think globalization is so recent, but it isn't. In fact, globalization is what colonialism is partly all about so it was great for me to be there at a time when the Australian social scientists and historians, and also New Zealanders, were beginning to discover and to think about Southeast Asia. So a lot of my colleagues were Australians and at places like Monash University where there were really exciting groups of scholars. So it immediately changed my notion of where exciting work is being done. It's not necessarily being done in the West. It's not necessarily being done in Britain. It's being done in Australia.

So, thinking of your original question, I think that in some ways that early work where I had to think through ethnicity — and I had to think it through with ethnic groups that I had no historical understanding of - was certainly was an excellent place for me to begin to develop some analytical skills and to be able to argue why something that other people didn't take seriously was, in fact, a site for really learning things. So I think this early work was really crucial and it led to the work that I did on ethnicity and race in militaries. I am also glad that I came into feminism through racial politics and in countries that most people don't take seriously.

STAR: Where do you see this type of research going? What research do we need to do in the era of globalization and increased militarization?

Enloe: Well, I really do think that site specific research is really still important. I think one of the things that are happening right 
now is that funding agencies don't want site specific research. Researchers really have to withstand this pressure and argue against it every time somebody wants you not to be a site specific specialist. Whether it's Johnson County, Kansas, or it's Kuala Lumpur, or it's the supermarket outside of Lawrence, I think getting a kind of depth in one site and seeing the complexities and the puzzles and the things that are not easy to understand, is so crucial for any kind of research and especially for, or including, feminist research. So I would argue with the "sexiness" of globalization in that a lot of people are tempted to think that they just have to be a specialist in the flows without actually having any in-depth work or time. So if one is to understand sex trafficking - which I think we just barely understand how it works - it is important to actually spend time in Milan, or to spend time in Albania, or spend time in the Ukraine, or to spend time in one part of Chicago where the Ukrainian women are being trafficked. And to realize that, in fact, flows themselves are not sort of up in the stratosphere, but flows are Starbucks coffee, or the trafficking in maids, or whatever one is looking at in terms of globalization. It's really important to have that grounding, which means site-specific research needs a different kind of investment in time.

I think there is a great tendency to want to get one's research done rather quickly so one can get the first articles out and then the book. And I don't think we can short cut the time that it takes to get to know one place. Which means we also have to have the skills - partly ethnographic, sometimes geographic, sometimes political economic, and even just plain old observation skills, which you've got in sociology - to do this research. We need to resist the temptation that we no longer need area specialists but that what it means to be an area specialist may change.

One of the things I'm particularly pleased about is that American studies is in some quarters beginning to take on global issues. In fact, there's going to be a new book coming out by Amy Lang at Syracuse University who's an American studies person in literature, but American studies set within the context of imperialism studies. And I think this is a very good route for American studies to get out there and be in the dialogue of other specializations. 
Somehow if you're an American studies person, or you're a sociologist that does most of one's work on America, then somehow one imagines you don't have to do a comparative study. I think the big problem with sociology - the way it's taught in most sociology departments in the United States and Britain - is that it tends not to be cross-national. Sociology in the U.S. is often about American studies, which is fine, but American studies is actually testing itself with Asian studies and black American studies. That's my pitch, my sermon for the morning.

STAR: So talking about decentering the study on America, do you mean we need to put ourselves in a global context?

Enloe: Absolutely, absolutely. One of the distinct features about the United States is that it's been globalized ever since the first Native Americans crossed the ocean straits. It's never been sitting by itself. But the temptation by Russian specialists, and Chinese specialists, and U.S. specialists especially, is that their respective countries are so diverse geographically and in population that it takes so much energy, time, and sometimes money, to get a grasp on what's going on in that country that one thinks, how could I possibly get up to speed to do any kind of serious comparison with anything else out there in the world? But I think China specialists have stepped outside of their China specialty and the U.S. people can do that as well; it just makes you smarter about the U.S.

STAR: In your talk yesterday, and then in your interview today, one of the things that struck me was that the way that political economy operates is through the role of mothers.

Enloe: One of the things I think is interesting in feminist studies is that we've made motherhood an interesting concept through which we can make better sense of things like the international garment industry, or elections and the political sociology of elections. It's not that we should become less interested in motherhood itself, but we should look at how it's constructed and who has a stake in it. And what we're learning is that a lot of people have had a stake in the concept of motherhood, controlling the concept of motherhood and controlling both men's and women's relationship to mother- 
hood, than we've ever imagined. All the people who are doing work on social welfare policies, and neo-liberal capitalist challenges to social welfare policies - whether they be in Germany, or Canada, or the U.S., or Japan - are realizing that the state has had a huge investment in motherhood. People, for all those years, who have tried to understand the nature of the state, the construction of the state, the fragility of the state, the reconstruction of the state, the transformation of the state have done that work but thinking that they'd never have to give a single thought to motherhood. And I think that they're naive. States wouldn't be so active in trying to construct, reconstruct, control, and enforce their notion of motherhood if they didn't think it was crucial to controlling and maintaining the state.

So we should not be letting go of the idea of motherhood, but watch who wields it and when they're successful and when they're not. A lot of people wielding it are in fact very masculinized actors in masculinized arenas: whether those be state bureaucracies, or state legislatures, or dominant media. You can't make sense of the rise of Italian fascism without watching the Italian fascists trying to reconfigure Italian motherhood. But when a feminist tries to understand particular women then we're very conscious that it's somebody else who wants those women to think of themselves mainly as mothers; but that doesn't mean that we think that is the be-all and end-all of the women we're trying to understand. In fact, we're even posing it more as a question: why would, or do, particular women we are interested in-for example, women who are the main shoppers at large international grocery chains - mainly identify themselves as mothers? And who has a stake in those women thinking of themselves as mothers at times when they don't want to think of themselves as mothers? And the same thing is true with wives and marriage.

It is striking how nervous the current Republican leadership, both in Congress and in the White House, are about marriage - as if it is one of the pillars of their notion of national security. Which is interesting. And yes, it's about gay marriage. Yes, it's about welfare policy. But it's really about the state and their notion of the kind of nation it takes to prop up their notion of a regime. But that 
doesn't mean that when women go to the polls they will vote as mothers. In fact, one of the things we need to know more about is when any woman goes to the polls, does she have any particular identity in mind? When women go to the polls and they pull that lever, or mark whatever ballot, or try to figure out what the electronic systems are- hopefully they don't have butterfly ballots in front of them-when they make their mark in the privacy of the ballot box, who do they think they are? Do they think they are the mother of a son in Iraq, in the military? Do they think of themselves as a woman who's just been denied a promotion? Who do they think they are? Or do they think they're the daughter of a father who's always voted Republican and they, for the first time in their lives, are not going to vote Republican - so they think of themselves, oddly enough, as a daughter, but a rebellious daughter?

Who do they think they are? That's a feminist question because it doesn't presume that you know who they think they are and it doesn't presume that they would make sense of elections or that making sense of the state is based upon a presumption of who they are. It's a different curiosity. It's true of garment workers in Vietnam; who do they think they are when they take their job? Who do they think they are when they decide to strike? Who do they think they are when they decide not to strike? Who do they think they are when they're laid off after having their first child?

One of my favorite writers about that is a sociologist at the University of Maryland named Seung-kyung Kim. Kim's a wonderful feminist sociologist, who's written a book called Class Struggle or Family Struggle? Lives of Women Factory Workers in South Korea, asking exactly those questions about women working in a Japanese owned electronics firm outside of Seoul in South Korea. She went in and worked on the assembly line in this electronics firm and wanted to know why older women were being laid off — older meaning 26. But she really wanted to know who those women that work in that electronics firm thought they were when they tried to make a very risky calculation as to whether they would join a pro-democracy demonstration out in the streets. Did they go out on the streets but realize they might lose their job and wouldn't have enough money to pay a dowry so that they 
could buy furniture for their new apartment that they and their fiancé worked for? Did they think they would jeopardize their marriage because they would lose their job if they went out on strike, or did they decide that they really were first and foremost citizens and therefore they were going to take the marriagability risk and still go out on the streets for the sake of being citizens? But you only ask those questions if you have a feminist curiosity.

STAR: Can you talk more about the feminist curiosity? What are you getting at?

Enloe: Well, it's funny. The reason why I gave my new book the name The Curious Feminist is because I realized that I began using the term widely. I first began using the term "feminist curiosity" because I do a lot of talks at different universities - which I like very much and believe it is a form of teaching - but during these talks, such as the one at KU yesterday, I could tell that there are students present who are required to come, especially undergraduates who would rather be somewhere else. So I began using feminist curiosity as a way to really persuade particularly the students in the audience, or even adults who were skeptical about feminist analysis, that they didn't have to be a feminist to use a feminist curiosity in order to make better analytical sense of issues.

I was asked by a wonderful research institute, the Institute for Gender Studies at Ochanomizu University in Tokyo, to do a series of lectures that were city-wide and were open to anybody. I decided to work with a translator because half the audience hassled with English and another half read English very well. In fact, there was a sociologist, Ruri Ito, one of the most influential Japanese feminist sociologists, who translated for me and she and I began using and flushing out what I meant by feminist curiosity for that set of audiences as well. Sometimes you begin using an idea just because it's easier and then realize that you really like it, which is what happened to me. I was using the term feminist curiosity in talks before I was using it in writing. So the book actually is influenced by the experiences I've had doing talks in the U.S. and in Tokyo. 
What it really began to mean for me, as I used it more, was thinking about the distinctive kinds of questions that feminists ask, or that people with feminist curiosity ask. And one of those questions are, for instance, under what conditions does any woman in any setting think of herself and what she's doing as a mother? Who do women think they are when they are shopping for Mexican winter tomatoes outside of Lawrence Kansas, for example, or working in an electronics factory outside Seoul Korea? That's using a feminist curiosity. Otherwise, if one is not a feminist, one might say, 70 percent of the assembly line labor in all internationally invested or joint venture electronic factories are women. That's a fact; no questions follow from that, and then we start talking about sweat shops, etcetera. But those with a feminist curiosity say wait, who do those women think they are? How do they act out who they think they are? Do they think they are single mothers with children? Do they think they are daughters trying to support their farming parents? A lot of women who work in international garment, and data entry - which is now very globalized - and electronics factories, think of themselves as farmers. But it takes feminist curiosity to first of all ask the question and then find the answers that you didn't even expect. And then when you hear that answer, then you begin to take that seriously and ask what that means for their relationship to labor organizing, to their relationship to the speed up of the assembly line, to their relationship to the product. Do they have a particular relationship to the product? If they're sewing jeans that are going to the GAP, do they have some relationship to that? If they're making NIKE sneakers in a coastal factory in China, or New Balance sneakers in a coastal factory in China, do they have some relationship to it? Do they think of themselves as consumers?

But you don't know that unless you have a feminist curiosity and the feminist part of the curiosity is that you actually take women seriously. You don't have to think they are angels, or that they're always heroic, or presume that they're always victims, but you always take them seriously. You always think that if I take these women's lives, experiences, and ideas seriously, I'm going to be smarter about whatever it is that I'm trying to understand, what- 
ever it is. What would the American presidency look like if you actually took seriously women as secretaries? Nobody has studied the U.S. Defense Department through the secretaries. They are the center of the organization and what makes them valuable is they are silent. Rose Mary Woods, Nixon's secretary, was one of the major figures in the Water Gate scandal. She took all the notes and was responsible for a lot of the tapes, but what so interesting was that her notion of being a professional secretary was "discretion." And you're saying, secretaries in the defense department know everything, but they never talk about it, do they? The presumption is they never would talk about it and they're never called before congressional hearings. Can you think of the last time a woman working as a secretary was ever called before a congressional hearing - the Abu Ghraib hearings for instance? No. There are two presumptions here: women who work as secretaries are socialized into, and the position of secretary is very compatible with, certain conventional notions of femininity. One of the key principles of secretarial professionalism is silence, otherwise known as "discretion." But it's so presumed that no investigatory hearings - the 9/11 commission, Senator Warner's hearings on Abu Ghraib - none of them called the people who would know: secretaries. The one secretary who just made the news is the secretary who remembers typing a memo by the Texas National Guard officer about whether George W. Bush as a young man did or did not receive favoritism in terms of his duties. Now that this secretary has finished her secretarial work, you notice that nobody really treats her as a serious source; she made the news, but she's not the serious source.

So I think secretaries in very sensitive institutions are absolutely worth it — not to mention when you don't talk about sexual harassment. Or, not to mention the relationship between secretaries of different ranks; secretaries are very hierarchically ordered, you are as senior as your boss is in most cases. They know more about the marriage politics inside large organizations but part of discretion is you don't tell. There are very good sociological and anthropological books out on secretaries and the history of secretaries; they tend not to be in state organizations. 
STAR: How does what you had to say about the feminine sensibility have to do with the current war in Iraq and Abu Ghraib in particular?

Enloe: In the lecture yesterday what I was trying to do there was to get all of us to take seriously four very specific - and all of them real-women. Two women are in the West who have been militarized: one as military wife and the other as an active duty soldier who has returned from Kuwait in an Iraqi operation. The other two are specific Iraqi women: one who uses the name Nimo and the other woman Jalil. Nimo runs a small beauty salon on one of the back streets of Baghdad, which is a place for women to talk about politics; but they claim they don't talk about politics. Jalil has become an "organizer" of women, particularly around issues of security and representation. But the thing about Abu Ghraib that I've been thinking a lot about is if one has a feminist curiosity what do they ask about that you otherwise would not ask? I was asked to do a piece for a very cross-disciplinary journal called the Asian Journal of Human Studies that comes out of Ewha University, the premier women's university in South Korea; this university is sort of Wellesley, Radcliffe, and Bryn Mawr, all wrapped up together in South Korea. Ewha University asked me to do a piece and it was interesting because I was thinking so much about Abu Ghraib and thinking that we only have the tip of the iceberg. We're further down below the tip than we were back in April, we've gotten down several layers, and we're beginning to ask much better questions about what went on. There have been some very good investigative journalists who are following this story. Eric Schmitt is one; he has followed U.S. internal military politics since the late 80 s, early 90 s, and was the guy who really helped break the Tailhook Scandal. There have also been several other really good journalists at the Washington Post. So I use really good investigative journalists as well as what is coming out of Human Rights Watch, what's coming out of other human rights investigators, and what's coming out of the Senate, as well as some of the Senate reports, especially the Taguba Report. General Taguba is the highest ranking Filipino-American officer in the U.S. today. 
So the first thing that I noticed was how the media made Lynndie England "the" story. And I am very interested in that but I didn't want to get carried away on the media side. There are a lot of you sociologists who are much better at American media coverage and the gendering of stories. I'm very nervous sometimes because people take the easy way out and look at print media because it is there in the archives and they can go back. It's much harder, unless you know immediately, that this is going to be something you want to write about. It's much harder to cover television coverage because you have to know immediately and then you have to start watching, which I think is one of the problems with media investigations by social scientists.

The second thing is that too few social science investigators look beyond what the editors, the publishers, and reporters put out there, to what readers read. It's as if the main set of photographs or the main coverage is to know what readers actually think. So what is happening in film studies, a lot of the new film studies people like Annette Kuhn, are looking at film goers as well as the films themselves. It's as if there were this really gripping film noir genre but once you take a look at movie-going statistics you found that literally nobody went to the movies, then you were kind of stuck with what's written on the films, but you have no idea what film goers think. Well the same is true in media sociology. So pay attention to the viewers. When they saw the movie what conversation did they have in the beauty parlor? What conversation did they have with their husband? What conversation did they have with their best friend in the board room or in their workplace? What conversation did they have about what the media's presenting: Lynndie England as the story? That is the cultural impact. I've not seen anyone trying to look at what consumers of the media have thought, in gender terms, of the Abu Ghraib story. I don't have the skills to do that, but I would love it if somebody would do it.

So I'm very interested in what went on in Abu Ghraib. And I try to imagine it like an ethnographic site. First of all, I'm very interested in that military police unit; it was a reservist unit, and it came from western Pennsylvania and West Virginia. But nobody 
has talked about questions like what was their training? What were the dynamics between men and men, women and women, women and men inside that unit from the time they were mobilized? What were the gender dynamics before they were deployed, and then right after deployment, and then when they first arrived? They arrived at a very specific time, because in September of 2003 the Pentagon, led by Donald Rumsfeld, ordered Geoffrey Miller, the general in command of Guantanamo, to look over the detention system in Iraq to see if, in productionist terms, the military detention system was generating enough "useful intelligence" information. And this military police unit of reservists, a lot of them quite young, came in October 2003 just after Geoffrey Miller had made his recommendations that the police-which included England and Graner's company - in Abu Ghraib should be more engaged in helping the military intelligence unit make the intelligence interrogations more productive. There is no evidence yet that they were specifically instructed to do specific things to the detainees that were on their cell block. We do know that they came in after Geoffrey Miller's recommendations to Sanchez, the main military commander at that time over the Iraq operation.

But we don't know what the gender dynamics inside of this military police unit were before they came into Abu Ghraib, in the first week, in the second week, in the second month. We do know that Lynndie England and Charles Graner began to have a sexual relationship, and out of that we know that Lynndie England is now wearing a camouflage maternity uniform when she appears at her court marshal hearings. But that has been just kind of brushed off. Now, you all, as smart sociologists, know that you never brush off the sexual dynamics inside of any organization we come to understand. And you also know that sexual dynamics inside of any organization are likely to be threaded with power inequalities; we don't know what they are, but we know that they existed. Yet no one has talked about that. There is kind of a salacious interest, versus feminist interest, in the Charles Graner-Lynndie England relationship.

In Pentagon and military reports these sexual dynamics are lumped together as lack of discipline, and there's no curiosity about 
it. We don't know what the sexual dynamics were, and masculinized dynamics were, inside the military intelligence unit; we don't know how masculinity was wielded between intelligence officers. In command of their unit was a military woman, a very senior officer, and she had just, with the whole unit, been transferred from Afghanistan. What is interesting is that nobody has asked what the gender dynamics were inside this mostly male military intelligence unit headed by a woman except they thought they are more senior than an ordinary police unit. But they were in Afghanistan, and now we know that the abuses of detainees in fact started earlier in Afghanistan than they did in Iraq; there are now investigations going on in the deaths of Afghan men who were detained in U.S. military camps in Afghanistan, and that same military intelligence unit was in operation there. So did they bring some of their presumptions about Muslim men, or some of their presumptions about the necessity to grind out intelligence, or their presumptions about the harshness necessary? Did they seem like serious interrogators? What did they learn in Afghanistan that they brought to Abu Ghraib? What then was the gender dynamics that created the military intelligence unit, I think it is called the $119^{\text {th }}$ battalion, and the military police? And unless we have a feminist curiosity about all of that, then we're never going to get to the bottom of it.

One of the problems with ethnography and globalization is that because this is globalization of abuse, it has crossed boundaries in all kinds of ways. Memos are one of the many things that are fuel for globalization. When Geoffrey Miller in Guantanamo gets a memo from the Washington defense department and then goes to Abu Ghraib to give advice to Sanchez, we're really talking globalization here: about interrogation methods, the globalization of interrogation methods, the globalization of intelligence, the globalization of security, the globalization of power. But ethnographies have to step outside then of the prison cell. So I have two things on my wish list. I want as full an ethnographic, feminist informed, study of Abu Ghraib as possible, including when the Red Cross people came in and weren't allowed to see the so-called ghost detainees who were hidden from them - which of course is a violation of international law. I want everybody in Abu Ghraib to be put on stage. And I 
want to see where gender matters, where masculinity and femininity matter, and how is it affected by power. Second, I want to take this new global ethnography and write in Guantanamo, the U.S. Senate, the Pentagon, and absolutely the Justice Department and the White House, but with an ethnographic curiosity.

STAR: With an ethnography, is it enough to do that or do we have to tie it into larger processes?

Enloe: We do now have new globalized ethnography skills. One of my colleagues who is in the sociology department at Clark, Parminder Bhachu, is a globalization ethnographer and she is teaching undergraduates as well as graduates how to do a globalized ethnography and she says you have to move out of the single site; you can't stand in just the village. Or, you can go to the village if you will, but you have to follow the flows out of the village and back again. You use the ethnographic site but you also ask what the larger connections are. So Parminder Bhachu has just written a book, which is a model of globalized ethnography, called Dangerous Designs. Dangerous Designs. It is a perfect example of how to do globalized ethnography; it is a study of the Indian fashion industry in London looking at Indian British women fashion designers who work with very class-diverse and ethnically-diverse Indian communities in London and watching their relationship with sewing pattern designers and garment makers in India. They use the fax machine to fax the designs back to India that are sewn up there and then they come back to their customers in Britain. What is also happening, and all this is part of globalization, is that Punjabi suit - the wonderful suits that have the long tops and then have the trousers underneath have become very popular amongst non-Indian, British fashionable women. Princess Dianna began wearing them; Cherie Booth, who is the wife of Prime Minister Tony Blair, herself a predominant lawyer, wears them. So Bhachu is looking at the globalization of what used to be an ethic outfit. And it would be good to actually ask her for her syllabi; how does she teach it? It's very interesting. So we're going to get, thanks to her and some other people who do globalized ethnographies, a better understanding of how globalization occurs. So I think as people who aren't 
anthropologists we need to read the current research of anthropologists to make our sociology and our political science more meaningful.

STAR: What about the Golda Meir, the Margaret Thatcher question about women who are in power?

Enloe: It's like Jeopardy, what is the question? So here's the question. Does the existence of, or our knowledge of, Margaret Thatcher, Golda Meir, and Indira Gandhi, as heads of government, throw a monkey wrench into the presumption that women are naturally anti-militarist and more peacemakers? First, I never use "naturally" anyway. What is true is that most women are situated in most societies so that they learn, and I think it is quite wise, to not have a stake in militarism. Although, in fact, many women, if they are going to join organizations and institutions like political parties that are headed for national power, or a bureaucracy that is going to try to make state policy, learn that you have to be able to feel comfortable with the wielding of military might in order to be taken seriously by the people who really control those political parties, who really control those bureaucracies. I'm not resorting to essentialism, I'm just saying that they learn, as do men, to be militaristic - there's nothing automatic that makes Dick Armey, for instance, a natural warmonger. So I think the response to that question is: be a curious feminist about Margaret Thatcher, be a curious feminist about Golda Meir, be a curious feminist about Indira Gandhi, and ask, what lessons did they learn from what masculinized institutions that led each one of them to adopt a highly militarized notion of national security and of state power? 